\title{
Glossophobia: The Fear Of Public Speaking In Female And Male Students Of University Of Karachi
}

\author{
Kausar Perveen \\ Department of Sociology \\ University of Karachi \\ Yamna Hasan \\ \& \\ Abdur Rahman Aleemi \\ Health and Hospital Management \\ Institute of Business Management-Karachi
}

\begin{abstract}
Individuals who have fear speaking publically suffer from strong fear in social performance situations and social sphere. (Stein, Walker, \& Forde, 1996).This research aims to investigate (a) if the level of anxiety is higher in females then males while speaking publically. (b) if students tend to be more anxious while speaking infront of opposite gender (c) if there is an association between reduction in public speaking fear in students and adaptation of effective psycho-physiological strategies for language learning. Samples of 126 undergraduate students have been selected in an equal ratio of male and female students from university of Karachi. Frequency and percentage analysis has been made to determine the level of public speaking fear in male and female students. A factorial ANOVA has been applied for comparative analysis of anxiety levels in males and females while presenting in front of the opposite gender. Further, a paired t-test has been applicable to determine if psychophysiological strategies for language learning are effective for reduction in glossophobia. The study affirmed that female students get more anxious then males while giving speech publically. It has also found that there is no effect of gender of audience on anxiety level of students during public speaking. Public speaking anxiety has a strong relationship with the adaptation of psycho-physiological strategies and can be reduced effectively.
\end{abstract}

Keywords: Glossophobia, Language Learning, Public Speaking, PsychoPhysiological Strategies, Speaking Anxiety.
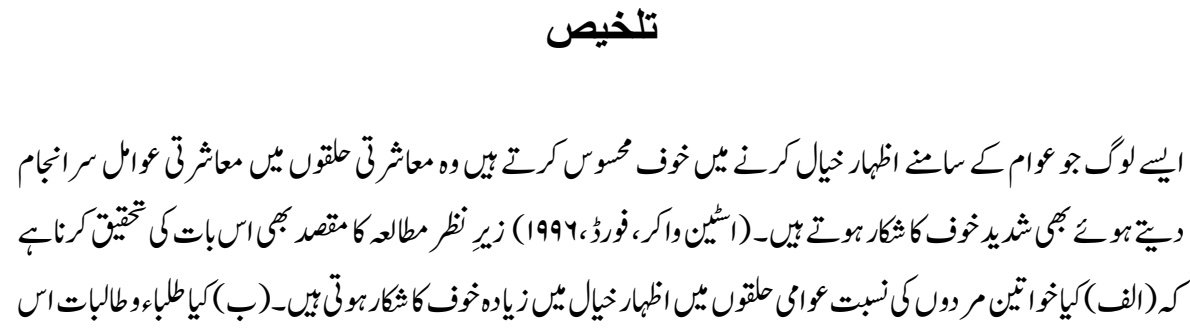


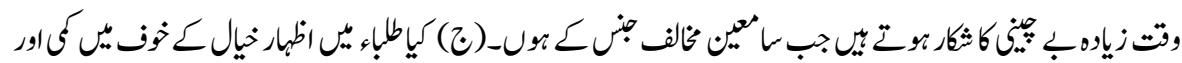

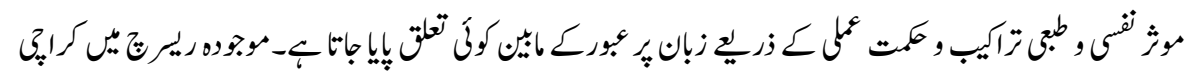

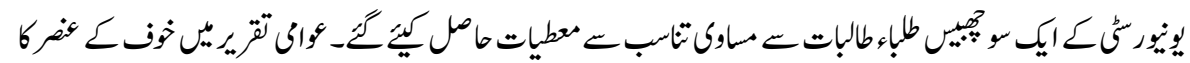

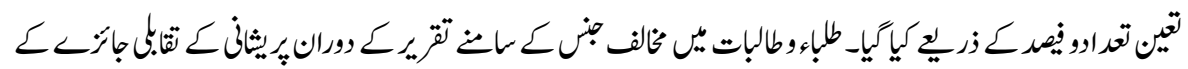

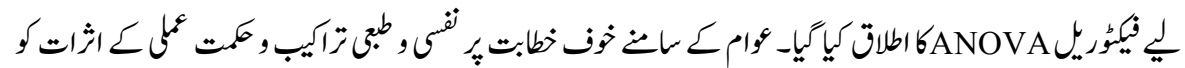

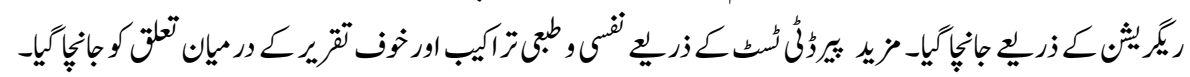

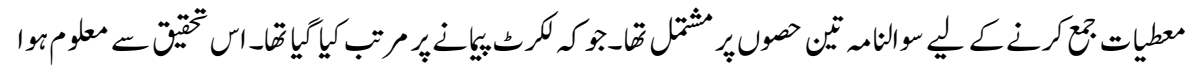

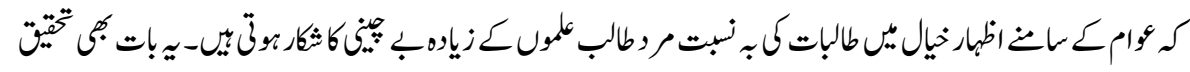

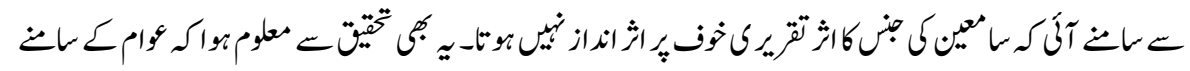

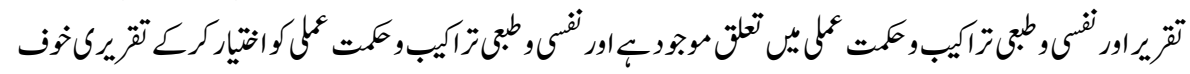

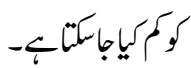

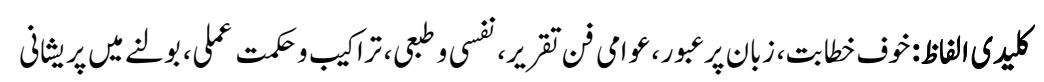

\section{Introduction}

Glossophobia, also known as "speech anxiety" is the feeling of fear while speaking in front of public, often characterized as fear of speaking publically or nervousness in communication. It is a feeling of panic related with different physiological changes like elevated heart and breathing rates, over-rapid reactions, trembling of muscles and shoulder and neck area stiffness among others (Tse, 2012). Glossophobia is a Greek originated word, glosso means tongue, and phobia means threat or fear (Ali \& Nagar, 2013). Public speaking fear is considered a type of societal dread that causes severe escaping of speaking in front of others because of fear of awkwardness or humiliation (Hancock, Stone, Brundage, \& Zeigler, 2010). It is a type of social phobia having great social importance, people with public speaking fear face great difficulty in pursuing their career goals and promotion, this may cause frustration, depression and distress in their personality (Mel Slater \& Barker, 2002). Glossophobia, along with performance nervousness, communication uneasiness, stage fright or fear of negative inference are categorized under social anxiety (Anke, Marcia, Anne, \& Westenberg, 2002).

Whereas, public speaking apprehensions are easily identified by various noticeable physical and psychological indicators, however, some of these are easily evidenced by spectators and are possibly caused by certain psychological pointers (Barlow, 2002). The most common symptoms include trembling or shaking of hands, mind going blank, 
difficulty in speech or in performances (Kushner, 2010). When public speaking fear arises in an individual, he or she usually hesitates to participate in routine activities; making him/her handicap and can erode the individual's quality of life (Hancock, Stone, Brundage, \& Zeigler, 2010). Similarly such conditions are also noted to cause anxiety in most of the cases as noted by (Horwitz, Horwitz, \& Cope, 1986) that anxiety is "the feeling of pressure, nervousness, tenseness, and worry associated with a stimulation of the autonomic nervous system", and is closely associated with the fear of speaking in public (Huang, 2012). By the same token Cunningham, Lefkoe, \& Sechrest, (2006), finds that public speaking fear is related to lack of courage to address public, however, on the contrary they argued that it is not necessary to cause failure in social milieu, people with speaking apprehension publically often are playing triumphant roles in society.

Notable differences are also found between genders, male and female speakers were observed to face different levels of fears while speaking in public. According to a survey, women were found to be more $(27 \%)$ anxious in public speaking then men $(14 \%)$ (Hancock, Stone, Brundage, \& Zeigler, 2010). Also the composition of the audience is also found to be significantly contributing in the same fashion. Many bodily and emotional symptoms have been identified in public speaking fear, and found to be directly related to the audience. Sometimes such fear can also cause symptoms of mental issues (Barlow, 2002). In the academic world in particular, and in our professional lives in general, often the ability of an individual is judged by his oral communicative performances, where people with public speaking fear usually ends up weakly (Bodie, 2010). Thus, leaving a void with the likelihood that their abilities may be judged wrongly (APA, 2013). Similarly, a significant relationship has also been established between Poor oral communication and lower educational results and lower levels of working ability as an employee (Goberman, Hughes, \& Haydock, 2015).

However, it is worth noticing here that, several academic programs and coursesparticularly at university level are designed to address and to train the students to cope with such symptoms. Most of these programs are aimed to transform the students into competent and professional communicators, to communicate, to express and advocate ideas effectively (Heng, Abdullah, \& Yusof, 2012). However, to the best of our knowledge, no such evidence exists - particularly, in the case of Pakistan to shed light on the fear of public speaking in our university students which may in turn become a token of indication of the effectiveness of these programs. Thus, this study is intended to fill this gap. Specifically, pertaining to the widespread issue of public speaking fear in university students, this study is designed to identify that whether female students feel more speaking anxiety in speaking publically or male students. Additionally, it is also a point of concern that the gender of audience greatly influences the level of fear in speaker students. Further, this study will shed light on whether the adaptation of psychophysiological strategies for language learning help to reduce the public speaking fear in university students, as it is noted by (Field, Duffy, \& Huggins, 2013) that psychological 
disorientation acts as a intervening factor in students' success. The main objectives of the study are to investigate (a) if the level of anxiety is higher in females then males while speaking publically. (b) if students tend to be more anxious while speaking in-front of opposite gender (c) if there is an association between reduction in public speaking fear in students and adaptation of effective psycho-physiological strategies for language learning.

\section{Brief Literature Review}

Many researchers have identified anxiety or fear of examination as an important type of social phobia that affect performance. Prevalence rate of this issue in western societies is 7-13 \% (Tillfors, et al., 2008). Daly, Vangelisti, \& Lawrence, (1989) and Allen, Hunter, \& Donohue, (2009) specifies in their researches that public speaking fear is a quite known form of social phobias, with great social emanations. Individuals who are afraid of speaking publically faces many challenges in pursuing their career goals and found limited scale for promotions, which leads to considerable personal agony, dissatisfaction, and gloominess (Pertaub \& Barker, 2002).

American Psychiatric Association specified in 2013 that the public speaking fear is one of the forms of social anxiety disorder in which mainly people have fear of negative estimation. It may be elucidated that up to $75 \%$ human behavior may affect due to this issue (McConnell, 2009).

A survey shows that approximately $21 \%$ of respondents ever suffer from this problem, in their view it may be tremendous and reason of great misery or evasion (Ruscio, Brown, Chiu, \& Sareen, 2008). People with this problem are unable to demonstrate their skills in different social situations, they feel uncomfortable and not only have fear of wrong estimation by others but also humiliation. Although they know that this fear is baseless but they suffer from severe anxiety in the feared situation, in turn they always stay away from the situation where they have to speak in public (Pertaub \& Barker, 2002). Knappe, et. al.(2011) estimated that $25 \%$ of youth also have an extensive fear of public speaking. Another survey explored that 34\% Canadian respondent found more anxious and confused as compare to others in the situation of speaking in public (Stein, Walker, \& Forde, 1996). A moderate definition suggests that speaking in the presence of large number of people may affect up to $75 \%$. (McConnell, 2009).

Conbeck, (2011) cite James McCroskey (1984), 30 to $40 \%$ of Americans suffer from Communication Apprehension that affects their ability and willingness to speak publically (Colbeck, 2011). Strahan (2003) explored that poor grades in studies also is the result of public speaking fear among students, rather than to overcome this fear they avoid to be acquainted to this situations, ultimately this fear is an obstacle in their career opportunity which might require public speaking. 
Stein, Walker, \& Forde (1996) have explored that approx 10\% of those who suffer from this problem specifically their life being affected in three spheres first during education second at work and third in their social life and relationships. It is also explored that despite the serious effects of disorder, mostly people are not intended to get treatment. If the disorder is not treated effectively it may become more serious problem, in result people are failed to have quality of life, they are unable to perform important social roles in society (Furmark, 2002). The seriousness of social phobia is due to remain untreated (Tillfors, et al., 2008). Many researchers have been putting their effort to investigate the therapy of this specific phobia; in this regard they have suggested that virtual reality exposure could be a possible therapy to treat specific phobias. (Pertaub \& Barker, 2002).

Yalçın \& İnceçay, (2014) defined that foreign language fear is another important phenomenon. Research shows it can be easily observed in class room activities. Students who have foreign language fear refrain themselves from such learning activities and have low performance as compare to non-phobic (Yamat \& Bidabadi, 2012). Anxiety associated to the adopted language lies of "self-perceptions, beliefs, feelings and behaviors related to classroom language learning arising from the uniqueness of the process for language learning" (Horwitz, Horwitz, \& Cope, 1986). Learning an adopted language is an exceptional problem in its nature because it tends anxious people to communicate in a language upon which lack perfection. (Tsiplakides \& Keramida, 2009).

Fluency in speaking foreign language is important to minimize the speaking phobia. If they have fluency in foreign language which is required to communicate than they can participate in classroom discussion fearlessly (Rajanthran, Prakash, \& Husin, 2013). Another concern related to foreign language anxiety is prestige of student in the presence of peers that confined them to speak caused by of the fear of negative estimation (Boath, Stewart, \& Carryer, 2012). According to the psychologist Grasha, (1987) and Meyer, (2009) this is the responsibility of the instructor to consider some interventions. Like, foster motivation, and classroom based debates to improve the foreign language skills of students. Instructors should analyze the capability of the students, their attitude and skills for oral communication, and to identify the reasons that cause their reluctance and lack of willingness to involve in speaking activities (Tsiplakides \& Keramida , 2009). One of the major causes of producing anxiety in students is speaking in the foreign language (Young, 1990). Student that suffer from public speaking fear are more profound to skip social events and gatherings. They feel hesitate to attend oral communication classes (Lynch, Correia, \& Cunningham).

\section{Tools and Methods}

Given, the overwhelming amount of literature exists and the various dimensions and factors being studied, along with several methodologies being followed. It does suggest 
that sufficient conditions exist for gender of speaker and audience to induce speaking anxiety and whether the adaptation of psycho-physiological strategies for language learning help to reduce that fear in university students. Hence to get hold of a meaningful theory, the following conceptual framework has been developed.

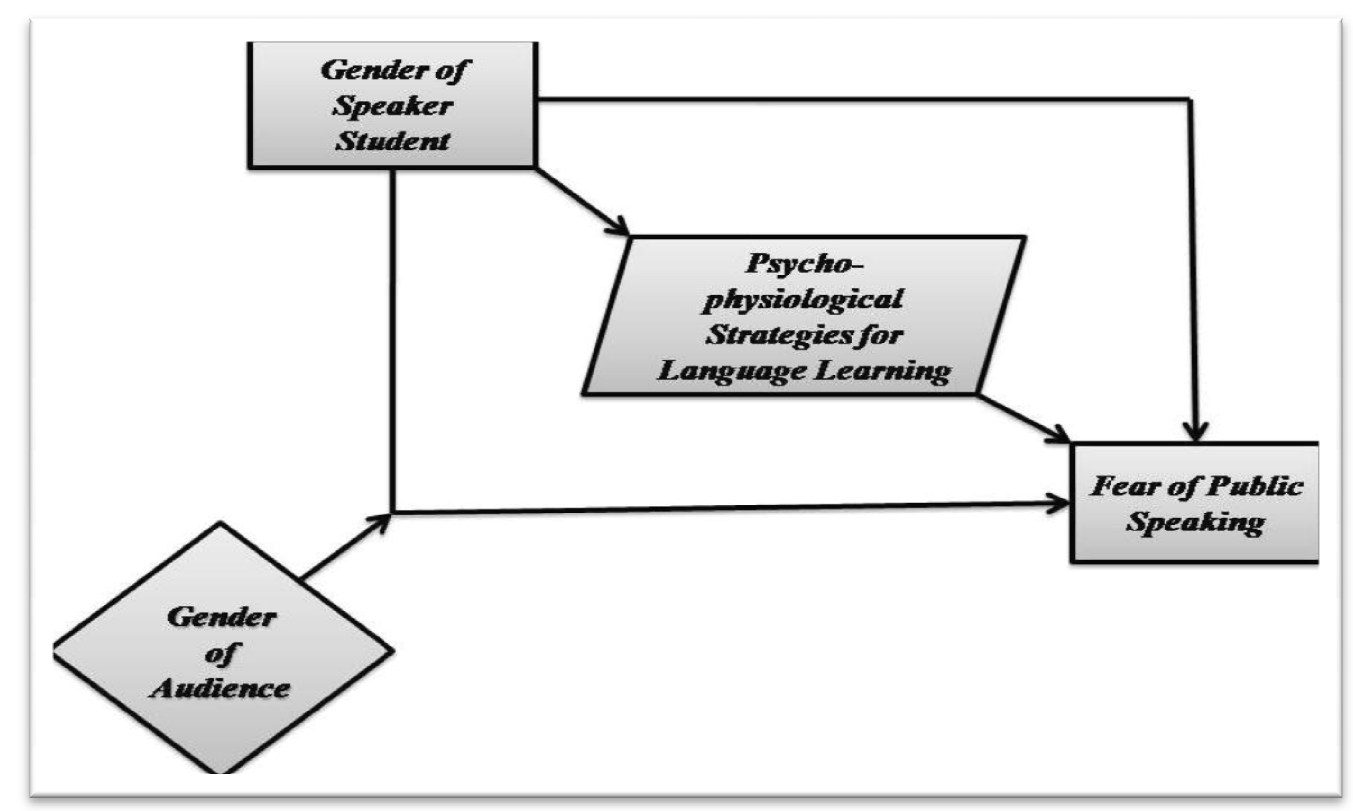

Figure 1: Conceptual Framework. Source: Authors' rendition

Given the above conceptual framework, a structured, self-reported questionnaire has been provided to the respondents to obtain the data. The instrument contained three parts of pre-validated items from different studies. First, from the work of McCroskey (1998) on "Personal Report of Public Speaking Anxiety (PRSPA)." This tool has been applied to evaluate the feelings of subject while speaking in front of against gender audience. Second, to compare the female and male scores of anxiety while giving a speech in front of majority female or male audience, a 7 items questionnaire has been used that is composed in regard of the Ethical Principle of Psychologists and Code of Conduct (American Psychology Association, 1999) (Razak, Yassin, \& Tengku Mohamad Maasum, 2017). Last, to determine the relationship between the adaptation of psycho-physiological tactic for language learning and the reduction in fear and anxiety of speaking publically, a 9 item questionnaire, developed by Kostic Bobanovic (2004), has been used. All three instruments were on 5-points likert scale answering pattern showing responses from "strongly disagree to strongly agree."

The target population is the undergraduate students of University of Karachi, which is one of the largest and prestigious institutions of the country. A total of 126 undergraduate 
students with equal proportions of male and female were surveyed on the basis of Convenient Sampling. The level of while speaking in public for both males and female students has been analyzed with pre-defined scoring ranging from; High, moderately high, moderate, moderately low and low. Further, a $2 \times 2$ between subjects factorial ANOVA has been conducted to compare the anxiety scores in female and male students while giving a speech in front of majority female or male audience. In addition, a paired t-test was applied to compare the reduction in fear of public speaking through adaptation of psycho-physiological strategies for language learning.

It was hypothesized in this study that:

$\boldsymbol{H}_{1}$ : The fear of public speaking is relatively more in female students then male students.

$\boldsymbol{H}_{2}$ : Female students tend to be more anxious while speaking in-front of majority male audience.

$\boldsymbol{H}_{3}$ : Male students tend to be more anxious while speaking in-front of majority female audience.

$\boldsymbol{H}_{4}$ : There is a positive reduction in fear of public speaking if students make use of affective psycho-physiological strategies for language learning.

\section{Results}

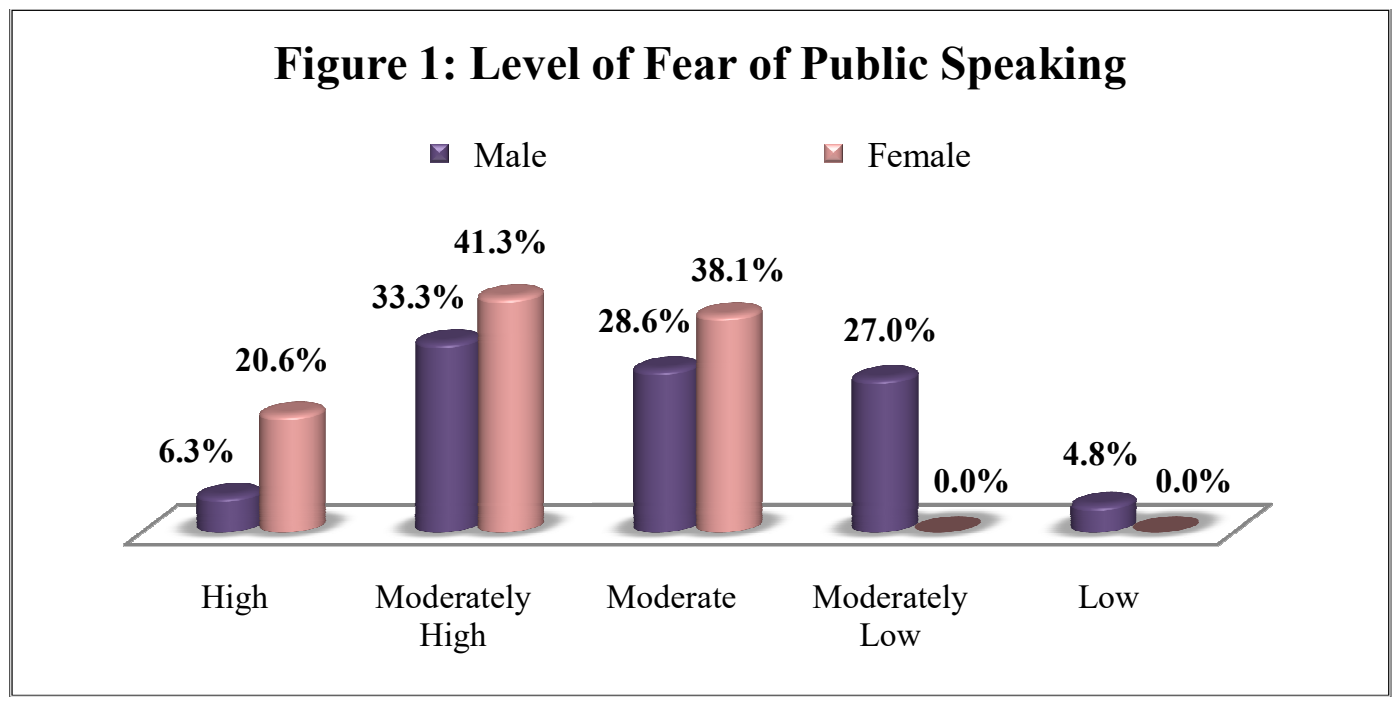

Out of the total 63 male respondents $33.3 \%$ reported that they have moderately high fear of public speaking, $28.6 \%$ have moderate fear, $27 \%$ have moderately low fear, and $6.3 \%$ have high fear while $4.8 \%$ have low fear of public speaking. On the contrary, out of total 63 female respondents, $41.3 \%$ have moderately high fear of public speaking, $38.1 \%$ have moderate fear, and $20.6 \%$ have high fear, while no female student reported moderately low and low levels of fear of public speaking. Hence, it is affirmed that the fear of public 
speaking is relatively more in female students as compared to male students in university of Karachi.

Table: 1

ANOVA

\begin{tabular}{|l|l|c|c|c|c|c|}
\hline & & $\begin{array}{c}\text { Sum of } \\
\text { Squares }\end{array}$ & Df & $\begin{array}{c}\text { Mean } \\
\text { Square }\end{array}$ & F & Sig. \\
\hline $\begin{array}{l}\text { Gender of Audience } \\
\text { (Ladies) }\end{array}$ & $\begin{array}{l}\text { Between } \\
\text { Groups }\end{array}$ & .071 & 1 & .071 & .229 & .633 \\
\hline & Within Groups & 38.730 & 124 & .312 & & \\
\hline & Total & 38.802 & 125 & & & \\
\hline $\begin{array}{l}\text { Gender of Audience } \\
\text { (Men) }\end{array}$ & $\begin{array}{l}\text { Between } \\
\text { Groups }\end{array}$ & .508 & 1 & .508 & 1.600 & .208 \\
\hline & Within Groups & 39.365 & 124 & .317 & & \\
\hline & Total & 39.873 & 125 & & & \\
\hline
\end{tabular}

The main effect for whether or not the gender of audience mattered was insignificant i.e .P(1.96) $0.229, \mathrm{p}>0.05$ in the case of all ladies audience and $\mathrm{P}(1.96) 1.600, \mathrm{p}>0.05$ in case of all men audience. It appears thatin both male and female students the level of anxiety is not any higher when in a situation of giving a speech to an all-male or female audience.

Table: 2

Paired Samples Test

\begin{tabular}{|c|c|c|c|c|c|c|c|c|c|}
\hline & \multicolumn{5}{|c|}{ Paired Differences } & \multirow[t]{3}{*}{ t } & \multirow[t]{3}{*}{ Df } & \multirow{3}{*}{$\begin{array}{l}\text { Sig. (2- } \\
\text { tailed) }\end{array}$} \\
\hline & & \multirow[t]{2}{*}{ Mean } & \multirow[t]{2}{*}{$\begin{array}{c}\text { Std. } \\
\text { Deviation }\end{array}$} & \multirow[t]{2}{*}{$\begin{array}{l}\text { Std. } \\
\text { Error } \\
\text { Mean }\end{array}$} & \multicolumn{2}{|c|}{$\begin{array}{l}\text { 95\% Confidence } \\
\text { Interval of the } \\
\text { Difference }\end{array}$} & & & \\
\hline & & & & & Lower & Upper & & & \\
\hline Pair 1 & $\begin{array}{l}\text { Fear of Public } \\
\text { Speaking - } \\
\text { Adaptation of } \\
\text { psycho- } \\
\text { physiological } \\
\text { strategies }\end{array}$ & -.31746 & .84523 & .07530 & -.46649 & -.16843 & -4.216 & 125 & .000 \\
\hline
\end{tabular}


Table: 3 (a)

Regression Statistics

\begin{tabular}{|l|l|c|c|c|c|c|}
\hline Model & & $\begin{array}{c}\text { Sum of } \\
\text { Squares }\end{array}$ & df & $\begin{array}{c}\text { Mean } \\
\text { Square }\end{array}$ & F & Sig. \\
\hline 1 & Regression & 5.611 & 1 & 5.611 & 10.580 & $.001(\mathrm{a})$ \\
\hline & Residual & 65.762 & 124 & .530 & & \\
\hline & Total & 71.373 & 125 & & & \\
\hline
\end{tabular}

a. Predictors: (Constant), Adaptation of psycho-physiological strategies

b. Dependent Variable: Fear of Public Speaking

Table 3 (b): Coefficient

\begin{tabular}{|l|l|c|c|c|c|c|}
\hline \multicolumn{2}{|c|}{} & \multicolumn{2}{|c|}{$\begin{array}{c}\text { Unstandardized } \\
\text { Coefficients }\end{array}$} & $\begin{array}{c}\text { Standardize } \\
\text { d Coefficient }\end{array}$ & T & Sig. \\
\cline { 2 - 6 } \multicolumn{2}{|l}{ Model } & B & $\begin{array}{c}\text { Std. } \\
\text { Error }\end{array}$ & Beta & B & Std. Error \\
\hline 1 & (Constant) & 1.59 & .295 & & 5.421 & .000 \\
\hline & $\begin{array}{l}\text { Adaptation of } \\
\text { psycho- } \\
\text { physiological } \\
\text { strategies }\end{array}$ & .328 & .101 & .280 & 3.253 & .001 \\
\hline
\end{tabular}

a. Dependent Variable: Fear of Public Speaking

Furthermore, adaptation of psycho-physiological strategies have a significant effect on lowering public speaking anxiety in university students, $t(126)=4.216 ; p<0.05$. Also through regression statistics it has been analyzed that there is $79 \%$ association between fear of public speaking and adaptation of psycho-physiological strategies $(\mathrm{F}=10.580$, $\mathrm{p}<0.05)$. According to t-test and regression analysis, it can be concluded that higher levels of public speaking anxiety in students can be reduced by the adaptation of adequate psycho-physiological strategies.

\section{Conclusions}

The study gave a clear insight of the fear of public speaking in university students of Karachi. It can be concluded from the study that female students have relatively more fear of public speaking then male students, as they have found mostly at moderate and moderately higher levels of public speaking anxiety some of the male students reported with elevated levels of anxiety while some also found with moderately low or low levels. It was also perceived that may be the gender of audience have some influence on the anxiety of speaker students (Mohamad \& Wahid, 2009), but the study has affirmed that the anxiety level of speaker students have no effects from the gender of audience. Further it is also deduced from the results that, by adapting the psycho-physiological strategies of 
language learning, the public speaking fear can significantly be reduced. It can be concluded that anxiety typically affects physical actions when an individual with this disorder acquainted to speaking publically, but this disorder is controllable through the adoption of different strategies (Khan, Ismail, Shafique, Ghous, \& Ali, 2015). Thus, it is recommended to the students who feel fear while speaking publically, to adapt some psycho-physiological strategies, like listening to music, reading books, discussing the issue with a person they trust, language learning, writing their experiences in a diary etc. to ease their nerves, so that they can successfully get rid of this kind of social anxiety. This can make their quality of life better and may lead them to progressive career and future endeavors.

\section{Recommendations}

Despite the significant presence of speaking anxiety, there are a number of ways defined by the researchers that focus on reducing the glossophobia especially in students. Some effective psycho-physiological strategies are provided here in for practical implications.

1. Exposure therapy is one of the best suggestions by the Finn, Sawyer, \& Schrodt, (2009). They stated that "graduated exposure involves presenting [students] with a threatening stimulus for short periods of time ranging from a few seconds to a few minutes, depending on the noxiousness of the stimulus."

2. Cognitive modification has also proved to be an effective strategy for the people with public speaking anxiety that emphasizes first on realizing about the fear and hesitation for speaking publically and then train your mind to cope with it by putting yourself in imaginary situations of giving speeches (Fremouw \& Scott, 1979).

3. It is also recommended to do some exercise before the speech session to reduce the adrenaline levels like aerobic exercise, deep muscle relaxation, visualization strategies and deep rhythmic breathing. These techniques are considered helpful in fight and flight situations (Westwick, 2014).

4. Listening to broadcasting sessions and some light music also calms the nerves and makes the speaker comfortable in delivering the speech (Tse, 2012).

5. Instead of a monologue it is recommended to have a dialogue session with some friend or a person speaker feels comfortable with.

6. Also to write the vocabulary and experiences in the diary enables the learner to grasp on the foreign language early. 


\section{References}

Ali, N. \& Nagar, R. (2013). To Study the Effectiveness of Occupational Therapy Intervention in the Management of Fear of Public Speaking in School Going Children Aged between 12-17 Years. The Indian Journal of Occupational Therapy, vol.45:3, pp.21-25.

Allen, M., Hunter, J. E. \& Donohue, W. A. (2009). Meta-Analysis of Self-Report Data on the Effectiveness of Public Speaking Anxiety Treatment Techniques. Communication Education, vol.38:1, pp.54-77.

Anke, W. B., Marcia, J. W., Anne, C. M. \& Westenberg, P. M. (2002). The Relation between Public Speaking Anxiety and Social Anxiety: A Review. Journal of Anxiety Disorders, vol.23:3, pp.305-313.

Barlow, D. H. (2002). Anxiety and its Disorders: The Nature and Treatment of Anxiety and Panic, 2nd Edition. NEWYORK: The Guildford Press.

Boath, E., Stewart, A. \& Carryer, A. (2012). Tapping for PEAS: Emotional Freedom Technique (EFT) in Reducing Presentation Expression Anxiety Syndrome (PEAS) in University Students. Innovative Practice in Higher Education, vol.1:2.

Bodie, G. D. (2010). A Racing Heart, Rattling Knees, and Ruminative Thoughts: Defining, Explaining, and Treating Public Speaking Anxiety. Communication Education, vol.59:1, pp.70-105.

Colbeck, J. J. (2011). The Impact of a Fundamentals of Speech Course on Public Speaking Anxiety. The Journal of Undergraduate .

Cunningham, V., Lefkoe, M. \& Sechrest, L. (2006). Eliminating Fears: An Intervention. Wiley InterScience, pp.183-193.

Daly, J. A., Vangelisti, A. L. \& Lawrence, S. G. (1989). Self-Focused Attention and Public Speaking Anxiety. Personality and Individual Differences, vol.10:8, pp.903-913.

Field, R., Duffy, J. \& Huggins, A. (2013). Supporting Transition to Law School and Student Well-Being: The Role of Professional Legal Identity. FYHE International Journal. 
Furmark, T. (2002). Social Phobia: Overview of Community Surveys. Acta Psychiatrica Scandinavica, pp.84-93.

Goberman, A., Hughes, S. \& Haydock, T. (2015). Acoustic Characteristics of Public Speaking: Anxiety and Practice Effects. Speech Communication. Graduate Attributes at Murdoch University, pp.867-876.

Grasha, A. F. (1987). Short-Term Coping Techniques for Managing Stress. New Directions for Teaching and Learning, pp.53-63.

Hancock, A., Stone, M., Brundage, S. B. \& Zeigler, M. T. (2010). Public Speaking Attitudes: Does Curriculum Make. Journal of Voice, pp.302-307.

Heng, C. S., Abdullah, A. N. \& Yusof, N. B. (2012). Investigating the Construct of Anxiety in Relation to Speaking Skills among ESL Tertiary Learners. The Southeast Asian Journal of English Language Studies, vol.18:3, pp.155-166.

Horwitz, E. K., Horwitz, M. B. \& Cope, J. (1986). Foreign Language Classroom Anxiety. The Modern Language journal, vol.70:2, pp.125-132.

Huang, Q. (2012). Study on Correlation of Foreign Language Anxiety and English Reading Anxiety. Theory and Practice in Language Studies, vol.2:7, pp.1520-1525.

Khan, F., Ismail, S., Shafique, M. S., Ghous, K. \& Ali, S. A. (2015). Glossophobia among Undergraduate Students of Government Medical Colleges in Karachi. International Journal of Research (IJR) vol.2:1, pp.109-115.

Knappe, S., Beesdo-Baum, K., Fehm, L., Stein, M., Lieb, R. \& Wittchen, H. (2011). Social Fear and Social Phobia Types among Community Youth: Differential Clinical Features and Vulnerability Factors. Jounral of Psychiatric Research, vol.45, pp.111-120.

Kushner, M. (2010). Public Speaking For Dummies (2nd ed.), USA, . New Jersey, USA: John Wiley \& Sons .

Lynch, P. M., Correia, H. \& Cunningham, C. Public Speaking Anxiety: The S.A.D. Implications for Students, Transition, Achievement, Success and Retention. Murdoch University.

McConnell, C. (2009). Effective Oral Presentations: Speaking before Groups as Part of your Job. The Health Care Manager, pp.264-272. 
Mel Slater, D.-P. P. \& Barker, C. (2002). An Experiment on Public Speaking Anxiety in Response to Three Different Types. Massachusetts Institute of Technology.

Meyer, K. R. (2009). Student Classroom Engagement: Rethinking Participation Grades and Student Silence. The Scripps College of Communication of Ohio University.

Mohamad, A. R. \& Wahid, N. D. (2009). Mohamad, A. R. \& WahANXIETY AND SPEAKING ENGLISH AS A SECOND LANGUAGE AMONG MALE AND FEMALE BUSINESS STUDENTS IN UNIVERSITI INDUSTRI SELANGOR. Segi Review (Vol. 2, No. 2) , 65-84.

Pertaub, D. -P. \& Barker, C. (2002). An Experiment on Public Speaking Anxiety in Response to Three Different Types of Virtual Audience. Massachusetts Institute of Technology, pp.68-78.

Rajanthran, S., Prakash, R. \& Husin, A. (2013). Anxiety Levels of Foreign Language Learners in the Iep Classroom: A Focus on Nilai University's Intensive English Programme (IEP). International Journal of Asian Social Science, vol.3:9, pp.2041-2051.

Razak, N. A., Yassin, A. A. \& Tengku Mohamad Maasum, T. N. (2017). Effect of Foreign Language Anxiety on Gender and Academic Achievement among Yemeni University EFL Students. English Language Teaching, vol.73-85.

Ruscio, A. M., Brown, T. A., Chiu, W. T. \& Sareen, J. (2008). Social Fears and Social Phobia in the USA: Results from the National Comorbbidity Survey Replication. Psychological Medicine, vol.38, pp.15-28.

Stein, M., Walker, J. \& Forde, D. (1996). Public-Speaking Fears in a Community Sample: Prevalence, Impact on Functioning, and Diagnostic Classification. Archives of, pp.169-174.

Tillfors, M., Carlbring, P., Furmark, T., Lewenhaupt, S., Spak, M., Eriksson, A., et al. (2008). Treating University Students with Social Phobia and Public Speaking Fears. Wiley InterScience, pp.708-717.

Tse, A. Y. (2012). Glossophobia in University Students of Malaysia. International Journal of Asian Social Science, vol.2:11, pp.2061-2073. 
Tsiplakides, I. \& Keramida, A. (2009). Helping Students Overcome Foreign Language Speaking Anxiety in the English Classroom: Theoretical Issues and Practical Recommendations. International Educational Studies, pp.39-44.

Yalçın, Ö., \& İnceçay, V. (2014). Foreign Language Speaking Anxiety: The Case of Spontaneous Speaking Activities. Procedia - Social and Behavioral Sciences, vol. 116, pp.2620-2624.

Yamat, H. \& Bidabadi, F. S. (2012). English Language Learning Anxiety Among Iranian EFL Freshman University Learners. Research Journal of Applied Sciences, vol.7:8, pp.413-420.

Young, D. J. (1990). An Investigation of Students'. Foreign Language Annals.

Dr. Kausar Perveen is an Associate Professor in the Department of Sociology, University of Karachi.

Yamna Hasan is a student of MBA in the Health and Hospital Management, Institute of Business Management-Karachi.

Abdur Rahman Aleemi is a Senior Lecturer in the Health and Hospital Management, Institute of Business Management-Karachi. 